\title{
PENINGKATAN KEMAMPUAN MENGOPERASIKAN REFERENCE MANAGEMENT SOFTWARE ZOTERO DAN END-NOTE UNTUK GURU SMKN 6 MALANG
}

\author{
Aisyah Larasati \\ Program Studi Teknik Industri, Fakultas Teknik, Universitas Negeri Malang, Malang, Indonesia \\ *Penulis Korespondensi: aisyah.larasati.ft@um.ac.id
}

\begin{abstract}
Abstrak
Kewajiban untuk menulis karya ilmiah bagi guru mendorong pentingnya penguasaan reference management software agar kualitas sitasi dan daftar rujukan dalam karya ilmiah sesuai dengan format yang diinginkan. Kegiatan pengabdian kepada masyarakat ini bertujuan untuk memberikan pengetahuan dan keterampilan bagi guru SMKN 6 Malang tentang reference management software Zotero dan EndNote. Kegiatan pengabdian dilakukan selama dua hari. Selain itu, dilakukan juga survey tentang persepsi pelatihan tentang reference management software dan operasionalnya sebelum dan sesudah pelatihan. Selain itu, survey juga berisikan tentang persepsi peserta pelatihan terhadap penyampaian materi pelatihan. Dari hasil survey, diketahui mayoritas peserta pelatihan belum memahami reference management software dan pengoperasiannya. Setelah pelatihan, mayoritas peserta pelatihan berpersepsi bahwa Zotero lebih mudah untuk digunakan dibandingkan dengan End-Note. Mayoritas peserta pelatihan berpersepsi bahwa kedua reference management software yang diajarkan, baik Zotero maupun End-Note, mudah untuk digunakan dalam menulis sitasi dan daftar pustaka. Hasil survey juga menunjukkan bahwa mayoritas peserta pelatihan menyatakan tingkat penguasaan materi baik dan cara penyampaian materi oleh penyaji menarik serta interaksi penyaji dan peserta baik.
\end{abstract}

Kata kunci: Reference Management Software; Zotero; End-Note; Sitasi.

\begin{abstract}
The obligation to write scientific papers for teachers encourages the importance of mastering reference management software so that the quality of citations and reference lists in scientific papers are in accordance with the desired format. This community service activity aims to provide knowledge and skills for teachers of SMKN 6 Malang about Zotero and EndNote reference management software. The workshop activities were carried out for two days. In addition, a survey of the workshop participant about reference management software and operations was also conducted before and after the workshop. The survey also contained perceptions of workshop participants regarding the delivery of training materials. From the survey results, it is known that the majority of workshop participants did not understand the reference management software and its operation before attending the workshop. After the workshop, most of the participants perceived that Zotero was easier to use compared to EndNote. Most of the participants also perceived that the two reference management software taught, both Zotero and End-Note, were easy to use in writing citations and references. The survey results also showed that the majority of participants stated that the level of mastery of the material was good and the way the material was presented by the presenters was interesting and the interaction between presenters and participants was good.
\end{abstract}

Keywords: Reference Management Software; Zotero; End-Note; Citation.

\section{PENDAhuluan}

Dalam sistem Pendidikan, guru merupakan komponen yang paling penting dalam menentukan baik buruknya mutu lulusan siswa. Semakin tinggi kualitas guru, maka semakin bagus mutu lulusan yang dihasilkan. Seorang guru yang berkualitas tentuakan menghasilakan pembelajaran yang berkualitas juga. Pembelajaran yang berkualitas akan menghasilkan lulusan yang cerdas, kompetitif, produktif, inovatif dan berkarakter (Taib dkk, 2018).

Besarnya peran guru dalam kemajuan suatu bangsa membuat pemerintah melakukan sejumlah kebijakan guna meningkatkan pengembangan profesionalisme guru. Salah satu bentuk dari pengembangan profesi guru adalah pengembangan kemampuan guru untuk membuat karya tulis ilmiah (Aina dkk, 2015). 
Penulisan karya ilmiah bagi guru merupakan kegiatan yang sangat penting. Salah satu kewajiban untuk menaikkan jabatan adalah menulis karya ilmiah. Oleh karenaitu, sudah semestinya seorang guru mau, mampu, dan terbiasa melakukan kegiatan karyai lmiah (Dwijayanti dkk, 2017). Peran guru tidak hanya sekedar untuk mengajar,namun harus mampu melakukan penulisan artikel ilmiah dengan tujuan untuk melakukan pengamatan, pengembangan, dan inovasid alam proses pembelajaran.

Melakukan penulisan karya ilmiah tentu perlu menuliskan sumber referensi. Penulisan sumber referensi membutuhkan waktu yang cukup banyak karena perlu mencocokkan penulis yang ada pada isi karya ilmiah dan daftar rujukannya.Selain itu kita perlu menyesuaikan format penulisan referensi tertentu seperti format American Psychological Association (APA), American Sociological Association, IEEE, Harvard, dan lain-lain.

Reference Management Software adalah aplikasi yang bisa memudahkan dalam penulisan rujukan dengan membentuk database referensi. Selain itu Reference Management Software juga bisa mengubah format perujukan sesuai dengan format yang kita inginkan. Beberapa fitur lain yang ditawarkan oleh Reference Management Software adalah bisa dijadikan sebagai platform untuk kolaborasi dalam penulisan menggunakan jaringan virtual web collaboration, seperti academic social bookmarking (Francese, n.d.). Contoh dari Reference Management Software (RMS) adalah End Note, Zotero, Mendeley, Citavi, Colwiz, Jabref, Paperpile, dan Refworks.

Seperti yang diketahui sebelumnya, bahwa penggunaan reference management software sangat membantu dalam menyelesaikan permasalahan referensi. Dengan adanya reference management software, maka diharapkan akan memudahkan guru-guru dan tenaga kependidikan supaya dapat melakukan perujukan dengan jauh lebih mudah. Hasil studi (Basak, 2015a) menunjukkan bahwa RMS dapat membuat lebih akurat dalam pembuatan referensi dan sitasi daripada sistem manual.

RMS dapat berfungsi untuk menyimpan, mengatur dan memformat referensi dalam sebuah teks karya ilmiah dan memudahkan bagi peneliti untuk melacak literatur ilmiah yang sudah didapatkan, kemudian membaca dan menggunakannya dalam penulisan bibliografi karya ilmiah. Banyak manfaat yang bisa diambil dari penggunaan RMS dalam menulis karya ilmiah.

Tujuan dari kegiatan pengabdian kepada masyarakat ini adalah untuk meningkatkan kemampuan guru dan tenaga kependidikandi SMKN 6 Malang dalam mengoperasikan refercnce management software End Note dan Zotero, sehingga diharapkan guru lebih termotivasi untuk menulis karya ilmiah setelah mengetahui kemudahan menulis sitasi dengan benar dan cepat menggunakan End Note dan Zotero. Sehingga diharapkan dengan adanya pengabdian mengenai reference management software ini, pengajar dan tenaga kependidikan di SMK 6 akan lebih terbantu dan praktis mencari, mensitasi dan mengelolanya dalam penulisan karya ilmiah.

Zotero dan End Note merupakan salah satu software paling populer yang memiliki kemampuan untuk membuat kutipan dan daftar pustaka secara otomatis dengan berbagai macam gaya kutipan yang berbeda atau disebut juga reference management software (Watkins, 2013). Reference mangamenet software ini sangat berguna bagi penulis karena dapat otomatis secara cepat membuat kutipan dan juga daftar pustaka dari tulisan yang dibuat dan tentunya terhindar dari kesalahan dalam pengutipan. Zotero adalah alat penelitian digital yang membantu pengguna dalam mengumpulkan, memformat, dan membuat anotasi dari berbagi sumber (Winslow dkk, 2016). Zotero merupakan software open source yang dapat digunakan dengan mudah oleh penulis dan terintegrasi oleh website, online database dan repositori (Ray \& Ramesh, 2017) .

\section{METODE}

Data yang disajikan pada artikel ini dikumpulkan dengan menggunakan on-line survey. Total responden yang didapat sebanyak 20 orang. Responden yang terlibat merupakan seluruh peserta pelatihan penggunaan reference management software yaitu guruguru yang terlibat dalam pengelolaan jurnal SMKN 6 Malang dan guru SMKN 6 Malang lainnya yang berminat untuk menambah pengetahuan tentang reference management software Zotero dan End-note. Data dianalisis menggunakan statistik deskriptif.

Kuisioner yang digunakan pada on-line survey dapat diklasifikasikan menjadi dua. Kuisioner bagian pertama, diisi oleh responden sebelum pelatihan dimulai. Survey ini bertujuan untuk mengetahui persepsi awal peserta pelatihan terhadap keberadaan reference management software. Kuisioner bagian kedua, diisi oleh responden pada akhir kegiatan pelatihan. Survey ini bertujuan untuk mengetahui persepsi responden terhadap pelaksanaan kegiatan pelatihan.

Kuisioner bagian pertama terdiri atas lima pertanyaan, dimana dua pertanyaan berbentuk pertanyaan terbuka. Pertanyaan pertama terkait profil responden. Pertanyaan kedua terkait pengetahuan awal responden terhadap reference management software. Tiga pertanyaan berikutnya berbentuk pertanyaan tertutup untuk mengetahui apakah responden pernah menggunakan reference management software end-note, zotero, ataupun mendeley.

Kuisioner kedua dilaksanakan setelah pelaksanaan pelatihan. Kuisioner kedua terdiri dua bagian. Bagian pertama berkaitan dengan persepsi responden terhadap reference management software dan terdiri atas empat pertanyaan (1 pertanyaan terbuka dan 3 pertanyaan tertutup). Bagian kedua terdiri atas empat pertanyaan 
tertutup yang berkaitan dengan penilaian responden terhadap hal yang berkaitan dengan pelaksanaan pelatihan.

\section{HASIL DAN PEMBAHASAN}

Hasil survey awal ditunjukkan pada Tabel 1.

Tabel 1. Pengetahuan awal tentang Reference Management Software.

\begin{tabular}{ll}
\hline \multicolumn{1}{c}{ Response } & Persentase \\
\hline Tidak/belum tahu & $80 \%$ \\
\hline Sedikit mengetahui & $10 \%$ \\
\hline $\begin{array}{l}\text { Mengetahui dengan detail definisi } \\
\text { reference management software }\end{array}$ & $10 \%$ \\
\hline
\end{tabular}

Hasil pada Tabel 1 menunjukkan bahwa mayoritas responden belum mengetahui manfaat reference management software dan pengoperasiannya. Namun demikian, ada $10 \%$ responden yang telah mengetahui manfaat reference management software dengan detail. Hasil ini mengindikasikan bahwa mayoritas peserta pelatihan belum memiliki kemampuan dasar dalam mengoperasikan reference management software.

\section{Berpengalaman Mengoperasikan End- Note}

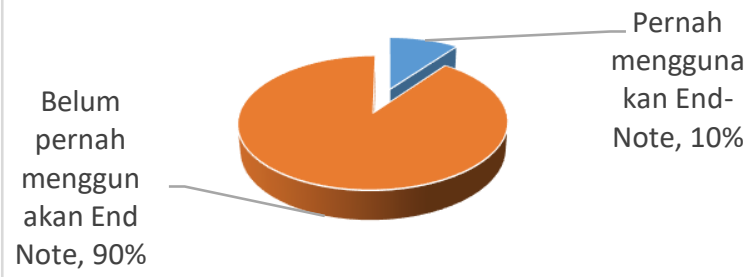

Gambar 1. Pengalaman menggunakan End-Note.

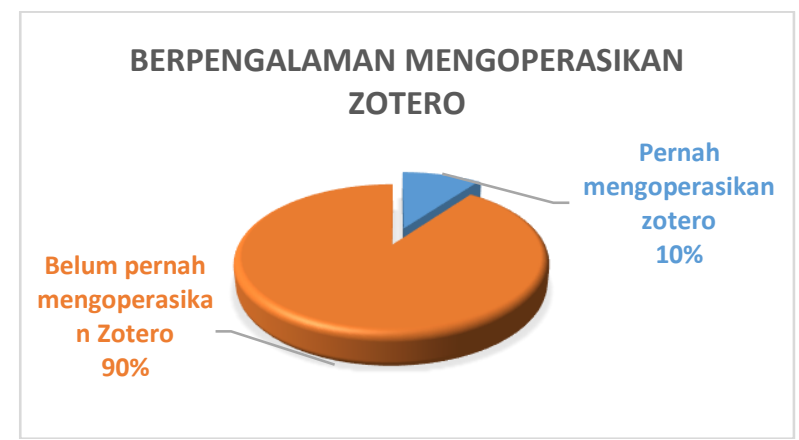

Gambar 2. Pengalaman menggunakan Zotero.

Hasil Gambar 1, Gambar 2, dan Gambar 3 mendukung hasil yang didapat pada Tabel 1, yaitu mayoritas peserta belum pernah mengoperasikan reference management software, baik Zotero maupun End Note. Hanya 10\% peserta yang sudah pernah mengoperasikan Zotero ataupun End Note. Hal ini mengindikasikan bahwa pelatihan harus diberikan mulai dari konsep dasar pengoperasian Zotero dan End Note.

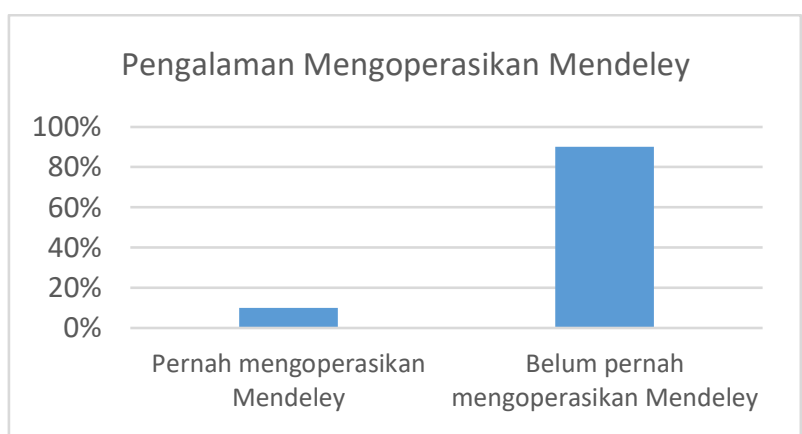

Gambar 3. Pengalaman menggunakan Mendeley.

Tabel 2. Pemahaman terhadap reference management Software.

\begin{tabular}{ll}
\hline Response & Percentase \\
\hline Tidak tahu & $5 \%$ \\
\hline Software untuk memudahkan sitasi & $30 \%$ \\
\hline $\begin{array}{l}\text { Software untuk menyusun daftar } \\
\text { rujukan }\end{array}$ & $35 \%$ \\
\hline $\begin{array}{l}\text { Software untuk memudahkan sitasi } \\
\text { dan menghubungkannya dengan }\end{array}$ & \\
daftar rujukan & \\
\hline Software untuk menyimpan referensi & $10 \%$ \\
\hline
\end{tabular}

Tabel 2 menunjukkan bahwa setelah mengikuti pelatihan, terjadi peningkatan pemahaman peserta pelatihan terhadap reference management dari yang semula persentase peserta pelatihan yang paham akan reference management software hanya $10 \%$, setelah pelatihan meningkat menjadi $95 \%$. Hanya saja, masih ada $5 \%$ peserta pelatihan yang tetap tidak mengetahui pemanfaatan reference management software.

Tingkat Kemudahan Mengoperasikan EndNote

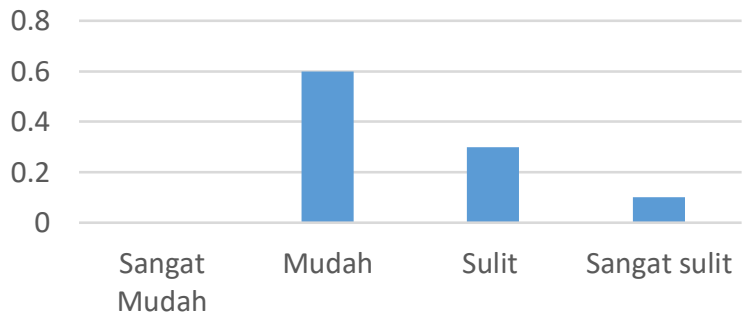

Gambar 4. Tingkat kemudahan menggunakan EndNote sebagai Reference Management Software.

Gambar 4 dan Gambar 5 menunjukkan bahwa mayoritas peserta pelatihan menyatakan bahwa reference management software, baik End-Note maupun Zotero mudah untuk digunakan. Reference management software (RMS) sangat membantu dalam mengelola referensi yang digunakan dalam penulisan karya ilmiah. RMS membantu menulis daftar pustaka ataupun membantu menuliskan sitasi sesuai dengan style yang dibutuhkan dalam waktu cepat. 


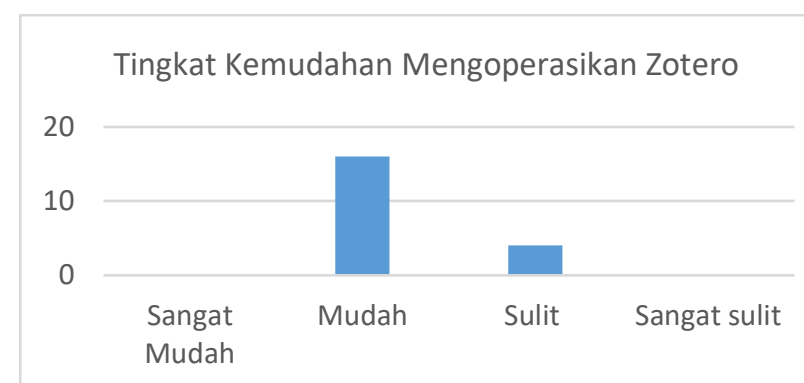

Gambar 5. Tingkat kemudahan menggunakan Zotero sebagai Reference Management Software.

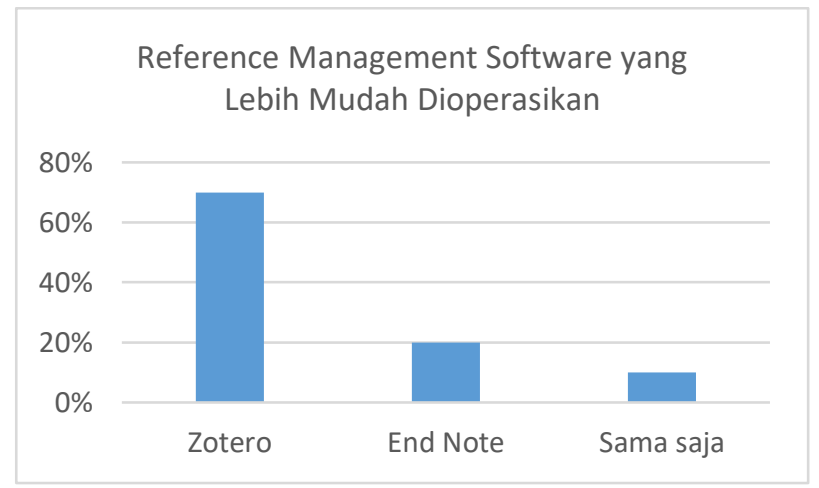

Gambar 6. Reference Management Software yang Lebih Mudah Dioperasikan.

Gambar 6 menunjukkan bahwa mayoritas peserta pelatihan berpendapat bahwa Zotero lebih mudah digunakan dibandingkan End-Note. Hal ini dapat disebabkan karena End-Note memiliki fitur-fitur yang lebih lengkap sehingga bagi pemula pemanfaatan fiturfitur yang lebih banyak menyebabkan kebingungan yang lebih tinggi.

Hasil pada Gambar 6 sejalan dengan studi yang dikemukakan oleh Ray \& Ramesh (2017) yang menyatakan bahwa Zotero banyak digunakan karena berbegai keuntungan yang ditawarkan, diantaranya: 1) Zotero menawarkan berbagai opsi untuk mengekspor data ke dalam software misalnya dengan menggunakan URL, Link, ISBNs, DOIs (Digital Object Identifier), PMIDs, arXiv IDs atau jika dokumen yang ingin dimasukkan telah di unduh, maka pengguna hanya tinggal drag and drop file dokumen ke dalam software zotero dan secara otomatis file dokumen akan tersimpan dalam repositori zotero; 2) Zotero menawarkan berbagai macam format style yang dapat menunjang gaya kutipan sesuai keinginan dari penulis; 3 )

Zotero memiliki kemampuan untuk memungkinkan pengguna mengambil informasi kutipan dari online dan memasukkan nya dalam database pribadi; 4) Zotero akan otomatis mengumpukan metadata seperti judul, pengarang, tahun terbit; 5) Informasi yang ada dalam Metadata yang telah disimpan dalam zotero dapat di ubah sesuai dengan keinginan dari pengguna; 6) Pengguna dapat membuat folder dan subfolder dalam hal memudahkan untuk mencari file dokumen sesuai dengan informasi yang diinginkan. Selain itu Kratochvíl (2017) menyatalan juga bahwa Zotero menghasilkan kesalahan yang lebih sedikit daripada RM software yang lain dalam hal referensi bibliografi (Kratochvíl, 2017).

Namun demikian, seperti yang ditunjukkan pada Gambar 6, 20\% peserta pelatihan lebih menyukai EndNote. Hal ini dapat disebabkan peserta tersebut memiliki kemampuan lebih untuk memanfaatkan fiturfitur yang ada pada End-Note. End Note merupakan salah satu software yang banyak digunakan para researchers memudahkan dalam membuat kutipan dan bibliografi dalam tulisan mereka. Seperti yang dikemukakan oleh Basak (2015a), EndNote digunakan oleh jutaan peneliti untuk mencari dan mengunduh artikel teks dari referensi yang dipilih, atau grup referensi dan itu (EndNote) memiliki lebih dari 5000 style untuk bibliografi nya. Beberapa keuntungan yang diberikan End note menurut beberapa ahli, diantarnya: a) End note memiliki kombinasi fitur yang sangat baik , mudah digunakan, dan menghemat waktu (Basak, 2015b); b)Pengguna dapat mencari bahan informasi dan mendokumentasikannya dalam bentuk kutipan ke dalam dokumen hanya dengan menggunakan EndNote (Fitzgibbons \& Meert, 2010); dan c) EndNote menyediakan 6750 style yang dapat digunakan dalam pengutipan sehingga dapat memudahkan pemilihan sesuai dengan keinginan dari penulis, dan style akan terus di upgrade oleh administrator (Kratochvíl, 2017). Selain itu, berdasarkan penelitian Kratochvíl (2017), untuk jurnal kesehatan seperti National Library of Medicine (NLM), EndNote sangat menguntungkan karena memiliki kesalahan yang paling sedikit daripada zotero dalam hal pengutipan menggunakan NLM style.

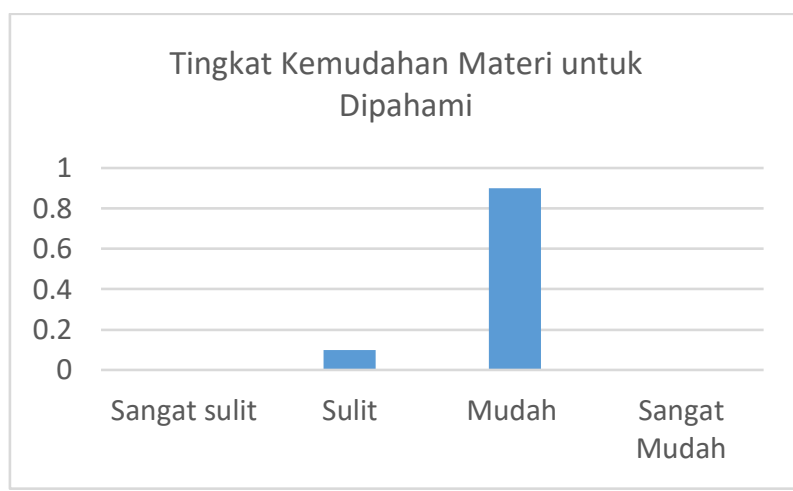

Gambar 7. Tingkat Kemudahan Materi Pelatihan untuk Dipahami.

Gambar 7 menunjukkan bahwa materi yang disusun oleh penyaji mudah dipahami oleh peserta serta mampu meningkatkan kemampuan peserta untuk mengoperasikan reference management software. 


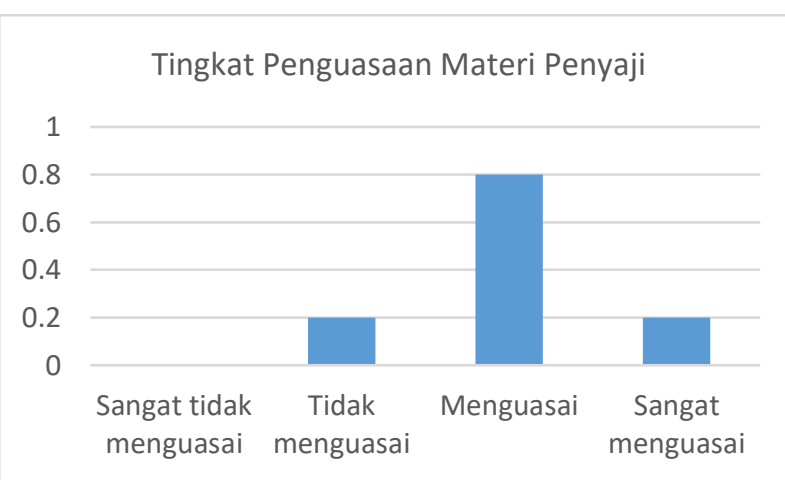

Gambar 8. Tingkat Penguasaan Materi Penyaji.

Gambar 8 menunjukkan bahwa mayoritas peserta menyatakan bahwa penyaji menguasai materi yang disampaikan. Namun demikian, masih ada $10 \%$ peserta yang menyatakan penyaji tidak menguasai materi. Hal ini menjadi umpan balik bagi penyaji untuk meningkatkan penguasaan materi sebelum memberikan pelatihan pada kegiatan pengabdian kepada masyarakat.

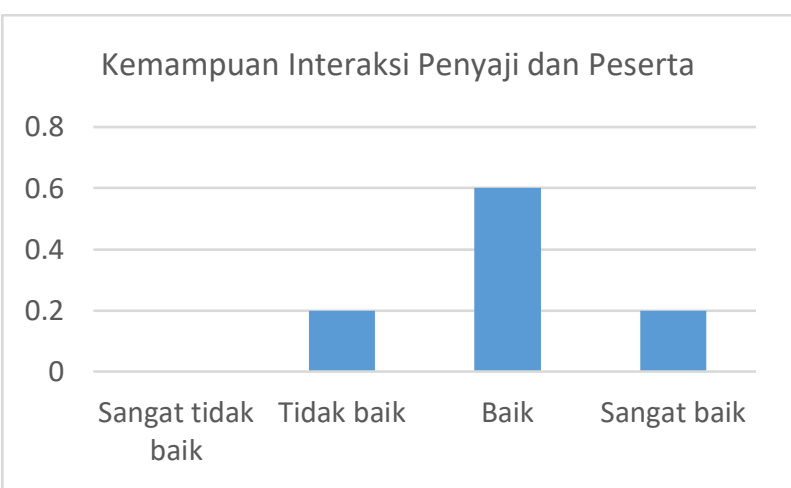

Gambar 9. Kemampuan Interaksi Penyaji dan Peserta.

Gambar 9 menunjukkan bahwa mayoritas peserta menyatakan interaksi penyaji dan peserta selama berlangsungnya pelatihan telah baik. Namun demikian, masih ada $10 \%$ peserta menyatakan interaksi tidak baik. Oleh sebab itu, untuk kegiatan pelatihan di masa mendatang, penyaji perlu mempertahankan eye contact dan interaksi dengan peserta selama pelatihan berlangsung.

Gambar 10 menunjukkan masih ada $20 \%$ peserta pelatihan yang menyatakan penyajian materi tidak menarik. Hal ini dapat disebabkan karena interaksi antara penyaji dan peserta yang tidak baik, sehingga peserta pelatihan merasa penyajian materi tidak menarik. Hal ini dapat menjadi masukan bagi penyaji untuk memperbaiki tampilan presentasi, gesture penyampaian materi yang menarik dan juga memberikan contoh yang lebih interaktif.

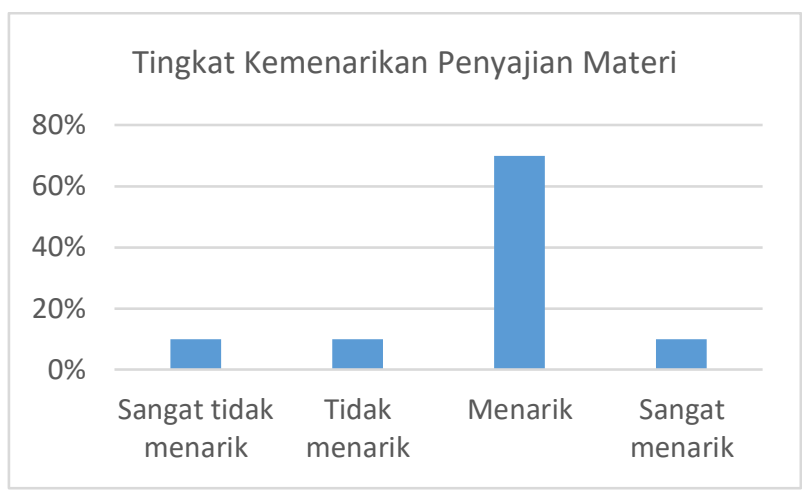

Gambar 10. Tingkat Kemenarikan Penyajian Materi.

Sebagai salah satu software yang paling banyak digunakan sebagai reference management software, setiap software pasti memiliki kelebihan dan kelemahan. Kelemahan dari Zotero diantaranya: hanya memberikan $300 \mathrm{Mb}$ free space untuk pengguna, Zotero tidak dapat mencegah dan menghapus item duplikat secara otomatis, tetapi dilakukan secara manual, Zotero memilki pilihan style yang lebih sedikit bila dibandingkan dengan End-Note, editing dan membuat style cukup sulit untuk dilakukan, serta sejauh ini, quick search bar dapat mencari referensi dalam single group library tetapi tidak dalam all group library secara bersamaan (Courraud, 2014; Kratochvíl, 2017; Ray \& Ramesh, 2017).

Sebaliknya, kelemahan End-Note diantaranya: Tingkat kesalahan dalam pengutipan nya lebih tinggi daripada zotero (Kratochvíl, 2017), dan search interface yang terdapat dalam EndNote terkadang tidak memberikan dokumen jurnal yang sesuai dengan keyword yang dituliskan (Fitzgibbons \& Meert, 2010).

\section{KESIMPULAN}

Berdasar hasil survey, dapat disimpulkan sebelum dilaksanakan pelatihan, mayoritas peserta pelatihan belum memahami manfaat reference management software dan cara pengoperasiannya. Setelah pelatihan, menurut sebagian besar peserta pelatihan berpersepsi bahwa Zotero lebih mudah untuk digunakan dibandingkan dengan End-Note. Kedua reference management software yang diajarkan menurut mayoritas peserta pelatihan mudah untuk digunakan dalam menulis sitasi dan daftar pustaka. Hasil survey juga menunjukkan bahwa mayoritas peserta pelatihan menyatakan tingkat penguasaan materi baik dan cara penyampaian materi oleh penyaji menarik serta interaksi penyaji dan peserta baik. Penggunaan reference management software dapat menghilangkan kesalahan dalam menuliskan daftar pustaka baik dari sisi kuantitas maupun style penulisan, memudahkan menelusuri referensi yang digunakan dalamkarya ilmiah, dan mengelola penyimpanan referensi untuk dapat digunakan pada penulisan karya ilmiah yang lain.

UCAPAN TERIMA KASIH

Ucapan terima kasih penulis sampaikan kepada Fakultas Teknik Universitas Negeri Malang yang telah 
memberikan support pendanaan untuk terlaksananya kegiatan pengabdian kepada masyarakat ini.

\section{DAFTAR PUSTAKA}

Aina, M., Bambang, H., Retni, S., Afreni, H., \& Sadikin, A. (2015). Pelatihan Penulisan Karya Tulis Ilmiah bagi Guru Guru SMA 8 Kota Jambi. Jurnal Pengabdian Pada Masyarakat, 30(3), 29-32. Retrieved from https://onlinejournal.unja.ac.id/index.php/jlpm/article/view/2 542

Basak, S. K. (2015a). A comparison of three reference management software: Jabref, zotero, and endnote. IJRIT International Journal of Research in Information Technology, 3. Retrieved from www.ijrit.com

Basak, S. K. (2015b). Analysis of the impact of NVivo and EndNote on academic research productivity. World Academy of Science, Engineering and Technology, International Journal of Social, Behavioral, Educational, Economic, Business and Industrial Engineering, 9, 3217-3222.

Courraud, J. (2014). Zotero: A free and open-source reference manager. Medical Writing, 23(1), 4648.

Dwijayanti, R., Marlena, N., \& Patrikha, F. D. (2017). Pelatihan Penulisan Karya Tulis (KTI) Bagi Guru-guru SMK di Kabupaten Jombang. Jurnal Pemberdayaan Masyarakat Madani (JPMM), 1(2), 249-266.

Fitzgibbons, M., \& Meert, D. (2010). Are bibliographic management software search interfaces reliable?: A comparison between search results obtained using database interfaces and the
EndNote online search function. The Journal of Academic Librarianship, 36(2), 144-150.

Francese, E. (n.d.). Usage of Reference Management Software at the University of Torino. https://doi.org/10.4403/jlis.it-8679

Kratochvíl, J. (2017). Comparison of the accuracy of bibliographical references generated for medical citation styles by EndNote, Mendeley, RefWorks and Zotero. The Journal of Academic Librarianship, 43(1), 57-66.

Ray, A. K., \& Ramesh, D. B. (2017). Zotero: Open source citation management tool for researchers. International Journal of Library and Information Sciences, 7(3), 238-245.

Taib, E. N., Masri, \& Taib, E. (2018). Kemampuan Guru SMA/MA dalam Mencari dan Membuat Kajian Teori (Kajian Analisis pada Karya Tulis Ilmiah Guru SMA, MA dan SMK di Kabupaten Aceh Barat Daya), (2014), 816-821.

Watkins, A. (2013). Zotero for Personal Image Management. Art Documentation: Journal of the Art Libraries Society of North America, 32(2), 301-313.

Winslow, R. R., Skripsky, S., \& Kelly, S. L. (2016). Not just for citations: Assessing Zotero while reassessing research. Information Literacy: Research and Collaboration across Disciplines. Fort Collins, CO: WAC Clearinghouse and University Press of Colorado, 299-316. 